\title{
PREPARING FOR A RETURN TO SCHOOL AFTER COVID-19: CREATING EMOTIONALLY HEALING SPACES FOR CHILDREN IN BRAZILIAN SCHOOLS
}

\author{
PLANEJANDO UM RETORNO ESCOLAR PÓS-COVID-19: CRIANDO ESPAÇOS \\ EMOCIONAIS CURATIVOS PARA AS CRIANÇAS BRASILEIRAS
}

Michael O’Loughlin ${ }^{1}$

\begin{abstract}
I explore the preparations necessary so that schools and classrooms are prepared to meet the emotional needs of students when schools reopen after the Coivd-19 pandemic has subsided. I discuss what factors a school planning team and individual teachers need to take into account in preparing for a return to classrooms. Children may suffer general anxiety due to fear of infection; they may suffer from loneliness, depression or purposelessness; they may have a crisis in their family due to loss of income; stress may place children at risk of domestic violence; and some children may have experienced bereavements. Children who come from black families or indigenous families are at greatest risk. Recommendations for identifying children at greatest risk are offered, as well as practical suggestions for how teachers can build an emotionally safe and healing classroom space that gives students a sense of security.
\end{abstract}

Keywords: Covid-19; healing space; emotional validation.

Resumo: Neste artigo, debato as preparações necessárias para que as escolas e as salas de aula estejam prontas para atender às necessidades emocionais dos alunos em seus processos de reabertura pós-Covid-19. Discuto quais fatores uma equipe de planejamento escolar e professores, individualmente, precisam levar em consideração na preparação para o retorno às salas de aula. As crianças podem sofrer de ansiedade geral devido ao medo de infecção; elas podem sofrer com a solidão, depressão ou falta de propósito; elas podem vivenciar uma crise familiar devido à redução de renda; o estresse pode colocar as crianças em risco de violência doméstica; e algumas podem estar passando por um período de luto. Crianças de famílias negras ou indígenas se encontram em maior risco. São oferecidas recomendações para identificar crianças em maior risco, bem como sugestões práticas de como os professores podem construir um espaço de cura na sala de aula que seja emocionalmente acolhedor e dê aos alunos uma sensação de segurança.

Palavras-chave: Covid-19; espaços curativos; validação emocional.

\section{Introduction}

How well and how easily children will recover from the effects of COVID-19 is likely to depend on a variety of factors including the level of mortality in a given community and possible deaths in students' own families; the degree to which children have been exposed to media coverage that might have fanned their fears and increased their sense of insecurity; and the duration of the lockdown period and any risks or vulnerabilities to which children might have been exposed during that period. Risks during lockdown include:

- Worry about infection to self or loved ones, possibly exacerbated by television or social media exposure to coverage of the pandemic

- increased vulnerability to domestic violence

\footnotetext{
${ }^{1}$ Adelphi University, New York, USA.
} 
- increased stressors due to poverty or overcrowded housing

- food or housing insecurity due to precipitous reduction in income owing to job loss or illness

- depression and anxiety that can emerge from a sense of purposelessness and lack of structure in daily life

- loneliness and emotional disconnection due to social isolation

- quarantine fatigue due to the indefinite duration of the lockdown

For children whose parents are healthcare workers or other essential workers who have labored in service jobs throughout the pandemic, the stressors are likely to be even greater due to living with the ever-present danger of infection and the risk of vicarious exposure to any traumas their parents may have witnessed or experienced. Due to the abnormality of the circumstances of hospitalization and dying during an infectious disease pandemic a great deal of unprocessed trauma may have accumulated in families due to restrictions in visiting family members afflicted with COVID-19 owing to fear of infection transmission, and similar restrictions on attendance at funerals and burials. Rituals of social solidarity for persons who are ill, and rituals of mourning that are designed to offer comfort for families who are bereaved have evolved over millennia and the rapid severance of these social rituals may impair or even terminate normal grieving processes leaving families with heavy or unmanageable psychic burdens.

A particularly worrying factor is that COVID-19 has affected poor communities of color disproportionately in Brazil and elsewhere. As the following report from The Guardian newspaper notes, the impact of COVID-19 has been most deeply felt in the poorest favelas in Brazil where poverty, overcrowding, and poor access to health care are endemic:

"There is clearly a difference in lethality for whites and non-whites," says Fernando Bozza, a researcher in infectious diseases at the government research institute Fiocruz, who co-authored the analysis of deaths by race published on 27 May by the Nucleus of Health Operations and Intelligence.

The researchers studied health service data on 30,000 patients diagnosed with Covid-19, who had either recovered or died by 18 May. It found that $55 \%$ of the black and mixed-race patients died, compared to $38 \%$ of white patients.

It noted that a black patient who could not read had nearly four times more chance of dying than a white university graduate, "confirming the enormous disparities in access and quality of treatment in Brazil".

A report by the Pública investigative media outlet showed more Covid-19 deaths in neighborhoods in Rio de Janeiro and São Paulo with majority black populations. According to health ministry figures reviewed by the Guardian, from 26 April to 23 May, the numbers of deaths of black and mixed-race Brazilians who died of Covid-19 after testing positive (where race was listed) increased 7.2 times, and white Brazilians 4.5 times.

"The majority of black people in our country are more vulnerable to contamination and more vulnerable in terms of access to treatment and health," says Rita Borret, a black doctor working in Jacarezinho, one of Rio's poorest favelas, who heads the black health study group at the Brazilian Society of Family and Community Medicine. "The pandemic has exposed these inequalities." (Phillips, 2020). 
Clearly, for teachers working in favela schools with a majority black population of children who are poor, careful consideration must be given to these racial disparities, and particular sensitivity must be used in helping children and families in such communities come to terms with the disproportionate suffering they have experienced. Such a discussion among school staff might be suitably widened out to understanding the potential role of schooling in either perpetuating or ameliorating racial inequalities. As the Black Lives matter movement in the United States illustrates, there are structural factors operating that increase suffering and risk for black populations, and, if anything, a greater ethic of care and nurture and awareness of racial injustice should exist in the schools black children - and indigenous children, who are similarly vulnerable - attend in order to improve their life chances in an inequitable society.

The picture is further complicated by two factors. First, there is the issue of the psychological condition of teachers and other school staff. Teachers may have experienced losses in their own families or communities, or indeed among their colleagues, and as human beings, teachers are as vulnerable to anxiety, dread, vulnerability, depression, purposelessness, financial insecurity, or quarantine fatigue as anybody else. It can be hard to offer support if you, yourself, are burdened with emotional stressors or anxieties.

In addition, it is widely recognized now that many children will return to school with significant academic deficits. These deficits may arise, in part, from inequalities in access to the internet and in ownership of computer laptops, tablets and smartphones in households. These inequalities will have prevented significant numbers of children from participating in online schooling. Students lacking such technological access could not possibly be expected to keep up with school work. A summary of a recent World Bank webinar ${ }^{2}$ on education in Brazil during the coronavirus noted:

\begin{abstract}
Unequal access to digital tools, connectivity and lack of training has imposed unseen challenges for governments, schools and teachers to engage students in long distance education during the COVID-19 pandemic. Such abrupt change affects all actors in the education systems, but low socioeconomic students may be hit critically: governments are concerning about the risk of deepening the already large learning gaps between socioeconomic groups and the rate of dropout rates (The impact of Covid-19 on Education in Brazil, 2020).
\end{abstract}

In addition, online instruction presupposes the capacity of parents to set up an appropriate instructional environment in their homes, and to supervise and assist children, as needed, in logging into online systems, following directions, completing assignments etc. Some parents may not have the emotional resources, the organizational skills, the time, the level of education, or the physical space to make this feasible for even one child, let alone for a family with many children. In addition, due to learning challenges, some children may be unable to benefit from instruction without direct teacher support and hence may be unable to learn independently at home. Furthermore, once schools reopen - assuming that the pandemic abates enough for an orderly sustained reopening - there is likely to be intense pressure on schools to make up for lost time, and to remediate student deficits, by applying intense pressure for academic outcomes that will demonstrate that children are making up ground academically. The risk is that this pressure will cause considerations of children's emotional and social needs to be set aside completely in the rush to get back to business as usual. The reality, however, is that if the emotional climate of

\footnotetext{
${ }^{2}$ See Webinário discute Educação durante a pandemia do novo coronavirus. Retrieved on June 16, 2020 from: https://www.todospelaeducacao.org.br/conteudo/Webinario-discute-Educacao-durante-a-pandemia-do-novocoronavirus/?utm_source=Banner\&utm_medium=Home\&utm_campaign=Webin\%C3\%A1rio.
} 
school is not attended to, and if the emotional needs of children are ignored, some children may never get back on track, may slip off their developmental trajectory, and may suffer from ongoing emotional and academic vulnerabilities that foreclose their futures. It is also possible that if children's distress manifests as aggression, resistance to schooling, or overt distress that schools, instead of seeking to understand the causes of these symptoms, may react punitively or harshlymisinterpreting a deep emotional struggle or behavioral regression as deviance or defiance - and creating a downward cycle of acting out behavior and ensuing punishment.

\section{School-wide planning for reopening}

School-wide planning is highly resource-dependent and will be much easier in schools that have the luxury of extra physical space where social distancing can be practiced, money for sanitization of surfaces, and where access to resource personnel such as nurses, psychologists, counselors or mental health workers - either as staff members or consultants - is freely available. In schools with mental health workers or nurses, it is essential that they be included in the reopening planning process. While others on the planning team will be concerned about how to implement social distancing and deep cleaning measures, if still required, to establish policies for health screening and mask wearing if necessary, and to figure out how to resume academic life and to make up for lost instructional opportunities, mental health workers should be represented in the school reopening planning process. In cases where there are no available mental health workers or nurses, some administrators and/or teachers should be charged with bringing mental health concerns to the table and ensuring that school leadership is aware of the mental health vulnerabilities brought about by the pandemic and that systematic measures are taken to safeguard the mental health of children as school life resumes. Here are some questions that school planning teams, administrators, and individual teachers ought to take into consideration:

- How are we to transition students to the reopening of schools?

- How do we cushion children if only a partial reopening is possible?

- How do we cushion children if a resurgence of the virus causes another sudden closure in the near future, or an extension of the current lockdown?

- How do we manage young children and adolescents emotionally if they have to wear masks and practice social distancing in their classrooms, cafeterias and playgrounds?

- How do we identify and support children who have experienced bereavements?

- How do we identify and support children who have experienced neglect, domestic violence, or abuse during the lockdown?

- How do we identify and support children who have experienced anxiety, depression despondency, or purposelessness as a result of the pandemic?

- How do we support teachers, seeking to contain and manage their own anxieties as well as the anxieties of their students?

When school reconvenes, careful planning needs to be done to ensure that the school responds as a caring community to create healing spaces for students. I believe that...

- Responding to the anticipated academic deficits of children by redoubling academic pressure will be counterproductive to children's emotional health.

- Responding to trauma-based acting out in children by redoubling disciplinary efforts will be counterproductive to children's emotional health. 
- Returning to "business as usual," with no attention paid to mental health, will be counterproductive to children's emotional health.

- If some form of remote instruction continues or has to be restarted due to a resurgence of the coronavirus, from a mental health perspective what improvements might be made to protect children with mental health vulnerabilities or special challenges during another extended period of remote instruction?

\section{A psychodynamic consultation model: School as a healing space}

From a psychodynamic perspective, creating healing spaces in schools involves paying close attention to children's emotions and recognizing that any overt behaviors (e.g., oppositional behavior, resistance to school work, fidgeting, withdrawal, nail-biting, aggression etc.) are only symptoms that offer clues to underlying emotional struggles. Jane Maltby, writing in the Journal of Child Psychotherapy in 2008 defined the role of a psychodynamically oriented mental health consultant in a school this way:

The approach, which I have developed, has been based on my belief in the importance of the struggle to understand, to make links, to facilitate thinking, rather than precipitately to solve problems, give advice and provide a solution which is so often what is asked for. Holding on to a psychoanalytic perspective, keeping a boundary, taking time to process can be difficult in a situation where there is much distress or pressure, in an environment where results are quantified in a very concrete manner and in which 'the expert' is viewed as omnipotent, or enviable or suspect or just plain rubbish. In the actual situation, I am attempting to note the unconscious meaning in what is being discussed, and to introduce a new dimension to the situation for thinking, reflection and integration.

What has become more and more apparent to me are the similarities of this way of working with my work with families, and how often situations of unprocessed loss can be the cause of disruption in the life of the individual, the family or the whole school community. What I aim to do, both working with families and consulting to schools, is to help the participants to find what they thought they had lost, to recognise what they still have at an internal level and to access this. Time and again I have been impressed by the way in which people can make use of outside help to galvanize their own inner resources and so get on with their lives once again. (2008, p. 98).

\section{Implications for school-wide planning}

- Mental health and healing concerns need to be placed squarely on the agenda when school reopening is being planned.

- A school mental health team should be prepared...

$\circ$ to offer school-wide guidance on emotional wellness planning and help administrators include a wellness plan in the reopening scheme.

o to screen children with vulnerabilities and set up support services.

- What preplanning does this require?

- Would a parent survey of child wellness be useful, prior to school opening?

- Can the school learn of COVID-19 deaths in the community, and be prepared to offer bereavement support to affected students? 
$\circ$ to offer training, advice, and guidance to teachers in creating healing spaces in classrooms.

- What provision for training will be offered to teachers in managing loss?

- Before resuming instruction, time needs to be set aside so that at a minimum, teachers have an opportunity to work in groups, preferably with an experienced facilitator or mental health consultant to process their own losses and feelings, and to help them understand how to build healing space for children to engage in similar work.

\section{Working directly with teachers to create healing spaces for pandemic-related anxieties and vulnerabilities}

For teachers and schools that routinely use student-centered class meetings for emotional processing, the creation of a space for emotionally processing the complex feelings induced by the pandemic should be a natural transition. But for teachers used to deploying a more didactic pedagogy in which students are passive consumers of teacher knowledge - the banking method of teaching described by Paulo Freire (1970) in Pedagogy of the oppressed-there will be a much greater learning curve. Ideally, for teachers, some opportunities to run such meetings initially in partnership with a mental health professional, more experienced facilitator, or colleague, might be very beneficial. It is also necessary to plan a school-wide support system so that teachers can refer students with significant vulnerabilities for more extensive support. Teachers may balk at taking on the responsibility of providing emotional support and assisting children in processing emotions. However, teachers typically serve as the key emotional contact point for children. Philippe Falardeau's (2011) movie, Monsieur Lazhar, for example deals with the aftermath of a suicide by a teacher who hanged herself in a classroom. The evidently traumatized children are served poorly by a bureaucratic and over-cautious administration, and by a rigid, rule-bound psychologist. Enter Monsieur Lazhar, an Algerian refugee masquerading as a teacher. He creates a space of acceptance and emotional receptivity in which these traumatized children can begin to speak and hence to heal. As Boris Cyrulnik (2010) reminds us in The whispering of ghosts, we should never underestimate the importance of a silent but deeply meaningful encounter, a moment of meeting or connection, that allows the child to experience him- or herself as loved. Max van Manen (1986) similarly noted in The tone of teaching, that every child needs to be seen and to experience being seen.

Here are some of the core principles of such work:

- Human connection is critical, and all children need to feel a sense of connection, whether working remotely or in a classroom.

- Checking in with students daily, whether online or in an actual classroom, creates a sense of social cohesion, community and belonging and creates a space where children can narrate their experiences and process their feelings.

- Such narration can occur through drawing painting, performance, listening and reacting to music, and creative writing, as well as through talk circles.

- A key component of this work is attuned listening. If difficult feelings emerge, a teacher can refer to school mental health staff, colleagues or school administrators for advice and guidance.

- Making contact with each child is vital. As Max Van Manen noted, every child needs to be seen, and to experience being seen [and heard].

- Without such opportunities for voicing experience no healing is possible. 
- Noted psychiatrist Donald Winnicott said that "every child longs for someone to bring understanding." "Why are such opportunities for receptivity and understanding so absent from so many schools?

- This work requires a shift from responding to behavioral symptoms [i.e., anger, anxiety, fidgeting, lack of interest, withdrawal, refusal etc.], and instead requires attuned empathy to seek to understand what distress a student is seeking to communicate.

- Can teachers make a commitment to creating a space to receive children's pain, anguish, and anxiety, and can administrators encourage and value such work?

- This work cannot occur unless a school administration makes a policy decision to apportion time for reflection, sharing, and healing school-wide and in individual classrooms.

- If teachers can listen mindfully and restoratively, children will speak their truths and will move through life less burdened and with more capacity for creativity, joy, and, when called for, the ability to mourn.

\section{Works cited}

CYRULNIK, B. (2010). The whispering of ghosts. New York: Other Press.

FALARDEAU, P. (Director). (2011). Monsieur Lazhar. [DVD].

FREIRE, P. (1970). Pedagogy of the oppressed. New York: Continuum.

MALTBY, J. (2008). Consultation in schools: Helping staff and pupils with unresolved loss and mourning. Journal of Child Psychotherapy, 34, p. 83-100.

O’LOUGHLIN, M. (2019). Engaging children in healing work. In M. Charles \& J. Bellinson (Eds.), The importance of play in early childhood education: Building lives. Lanham, MD: Rowman \& Littlefield.

PHILLIPS, A. (2007). The beast in the nursery: On curiosity and other appetites. New York: Vintage.

PHILLIPS, D. (2020, June 9). 'Enormous disparities': coronavirus death rates expose Brazil's deep racial inequalities. The Guardian. Retrieved on June 15, 2020 from: https://www.theguardian.com/world/2020/jun/09/enormous-disparities-coronavirus-deathrates-expose-brazils-deep-racial-inequalities.

The impact of Covid-19 on Education in Brazil. (2020). Retrieved on June 16, 2020 from: https://www.worldbank.org/en/events/2020/04/29/the-impact-of-covid-19-on-education-inbrazil.

VAN MANEN, M. (1986). The tone of teaching. Portsmouth: Heinemann.

\footnotetext{
${ }^{3}$ Quoted in Phillips (2007, p. 51).
} 


\section{Sobre o autor}

Michael O’Loughlin é Professor Titular na School of Education, docente e supervisor clínico e de pesquisa no Programa de Doutorado em Psicologia Clínica da Adelphi University, New York. Autor, coautor e organizador de oito livros, quatro dos quais relativos à vida emocional de crianças. Tem publicado extensivamente sobre problemas relacionados à infância. Foi co-presidente da Association for the Psychoanalysis of Culture and Society, e atualmente é co-editor do periódico Psychoanalysis, Culture and Society. É também editor da coleção Psychoanalytic Interventions: Clinical Social, and Cultural Contexts, publicada pela Rowman \& Littlefield.

E-mail: michaeloloughlinphd@gmail.com. 